\title{
MULTIMEDIA INTERAKTIF SEBUAH TEROBOSAN PEMBELAJARAN PAKET B
}

\author{
Dwi Sudarmanto, Yetty Widya KS. \& Yuni Ekawati*
}

\begin{abstract}
Due to a signicant increase of learning achievement using B Package using ICT it's strongly recomended to use multimedia in teaching mathetmaticts. Information and communication technology (ICT), is developing so fast. Its development is not easy to predict. Now a days, ICT is utilized by almost all aspects of human life including education. The research conducted was regarding the use of ICT to teach math. It was how influential interactive media can be used to facilitate instructional program of B Package to teach mathematics. Rasearch findings indicate that there is significant increase in learning achievement of $B$ Package program participants by using interactive multimedia. This article recommends, therefore, using ICT based instructions with variety of interactive multimedia.
\end{abstract}

Key words: interactive multimedia , instructional program,

\section{PENDAHULUAN}

\section{Latar Belakang}

Salah satu babak penting dalam perkembangan kemajuan manusia adalah kelahiran teknologi informasi, sebuah pola konvergensi yang menggabungkan teknologi informasi dan teknologi telekomunikasi yang sering disebut dengan Information and Comunication Technology (ICT). Kelahiran ICT oleh sebagian orang dipandang sebagai pemicu tumbuhnya revolusi teknologi dan revolusi berkomunikasi.

Cepatnya perkembangan teknologi informasi pada akhimya dijadikan indikator untuk memposisikan sebuah masyarakat dalam menghadapi perkembangan yang ada di masyarakat. semakin baik posisi dalam indeks teknologi informasi semakin maju dan sejahtera negara tersebut. Dilihat dari indeks Indonesia dalam pemanfaatan ICT pada dunia pendidikan, Indonesia berada di posisi baru menyadari pentingnya ICT untuk pendidikan dan pada tingkat applying (aplikasi), yaitu taraf belajar menggunakan ICT dan belum mengantarkan masyarakat secara integrating memanfaatkan ICT untuk belajar. Pada tahun 2004, Indonesia berada pada posisi ke 53 dari 64 negara yang mempunyai kesiapan untuk jaringan informasi global dan berada pada peringkat ke 53 dari 60 negara untuk kesiapan e-leaming.

Komputer dan perangkat multimedia lain sebagai bentuk konkrit dari ICT, cepat atau lambat pasti menjadi barang kebutuhan sehari-hari, termasuk dalam pembelajaran sebagai upaya meningkatkan kualitas pendidikan. Banyak orang percaya bahwa multimedia akan dapat membawa kita kepada situasi belajar dimana "learning with effort" (belajar dengan

\footnotetext{
* Pamong Belajar di BPKB Jawa Timur
}

dipengaruhi/terpaksa) akan dapat digantikan dengan "learning with fun" (belajar dengan menyenangkan). Jika situasi tersebut tidak terjadi, maka multimedia sekurang-kurangnya diharapkan akan dapat membantu belajar menjadi lebih efektif.

Penggunaan multimedia interaktif dalam pembelajaran sangat memungkinkan untuk meningkatkan kemampuan berpikir yang diharapkan. Kelebihan yang dimiliki multimedia interaktif, adalah dapat mempersiapkan sumber daya manusia melalui pendidikan yang berkualitas. Pada proses pembelajaran warga belajar diharapkan memperoleh kemampuan penalaran, komunikasi, pemecahan masalah, dan memiliki sikap menghargai kegunaan dari materi yang disajikan. Kemampuan-kemampuan tersebut melibatkan cara berpikir secara kritis, sistematis, logis dan kreatif yang sangat dibutuhkan pada era teknologi saat ini, misalnya dalam memilih dan mengelola informasi-informasi serta berkomunikasi.

Munculnya paham humanis pada dunia pendidikan memberikan pengakuan secara lebih luas bagi warga belajar sebagai subyek pendidikan, bukan sebagai obyek. Paham yang cukup berpengaruh dan banyak diaplikasikan dalam pendidikan adalah konstruktivis. Pandangan ini berpendapat bahwa semua warga belajar memiliki gagasan/pengetahuan sendiri tentang lingkungan dan peristiwa/gejala alam di sekitamya. Singkatnya, warga belajarlah yang mengkonstruksi pengetahuan dan pengalamannya. Kegiatan pembelajaran yang diselenggarakan diharapkan mampu untuk membentuk watak, peradaban, dan meningkatkan mutu kehidupan warga belajar. 
Kegiatan belajar mengajar seharusnya mampu memberdayakan semua potensi warga belajar untuk menguasai kompetensi yang diharapkan. Pemberdayaan ini diarahkan untuk mendorong individu belajar sepanjang hayat dan mewujudkan masyarakat belajar. Kegiatan belajar mengajar dilandasi oleh prinsipprinsip berikut: (1) berpusat pada warga belajar, (2) mengembangkan kreativitas warga belajar, (3) menciptakan kondisi menyenangkan dan menantang, (4) mengembangkan beragam kemampuan yang bermuatan nilai, (5) menyediakan pengalaman belajar yang beragam, dan (6) belajar melalui berbuat.

Berdasarkan paham konstruk-tivis dan prinsipprinsip pembelajar-annya di atas, maka pembelajaran media interaktif sangat memungkin-kan terwujudnya pembentukan watak dan peradaban peserta didik. Penggunaan multimedia interaktif dalam pembelajaran dapat meng-optimalkan peran indera dalam menerima informasi ke dalam sistem memori sehingga relatif lebih cepat dalam membangun struktur pema-haman warga belajar. Hal ini dikarenakan karakteristik yang dimiliki multimedia interaktif yaitu terintegrasi-nya komponenkomponen seperti suara, teks, grafik, animasi dan video.

Kelebihan-kelebihan yang dimiliki multimedia interaktif bermanfaat dalam membangun kemampuan berpikir matematika warga belajar, yang melibatkan cara berpikir dan bernalar melalui kegiatan penyelidikan, eksplorasi, eksperimen, imajinasi, institusi, penemuan melalui kegiatan prediksi, dugaan, mencoba-coba dan rasa ingin tahu, kemampuan pemecahan masalah dan kemampuan menyampaikan informasi atau meng-komunikasikan gagasan.

Dalam pembelajaran matematika konsep dan keterampilan tingkat tinggi yang memiliki keterkaitan antara satu unsur dan unsur lainnya yang sulit diajarkan dan dipelajari melalui buku semata, dapat disajikan melalui program-program multimedia. Kelebihan program multimedia interaktif dalam menjelaskan suatu konsep dapat menuntut warga belajar untuk bereksplorasi dan menganalisis, mencoba dan menggali konsep dan prinsip yang termuat dalam suatu materi yang dihadapinya sehingga relatif lebih cepat membangun struktur pemahaman warga belajar karena terintegrasinya komponen-komponen seperti suara, teks, animasi, gambar/grafik dan video berfungsi untuk mengoptimalkan peran indera dalam menerima informasi ke dalam sistem memori.

Undang-Undang No. 20 Tahun 2003 tentang Sistem Pendidikan Nasional (Sisdiknas), Pasal 4 ayat (1), menyatakan bahwa salah satu prinsip pe-nyelenggaraan pendidikan adalah "Pendidikan diselenggarakan secara demokratis dan berkeadilan serta tidak diskri-minatif dengan menjunjung tinggi hak asasi manusia, nilai keagamaan, nilai kultural, dan kemajemukan bangsa". Artinya, penyelenggaraan pendidikan harus meniadakan diskriminasi atau kesenjangan akses untuk memperoleh pendidikan yang bermutu.

BPPLSP Regional IV sebagai lembaga yang bergerak di bidang pengembangan dan pengkajian pendidikan luar sekolah sudah selayaknya mengembangkan sebuah media pembelajaran yang bersifat interaktif dengan memanfaatkan teknologi komputer. Dengan mempertimbangkan keterbatasan yang ada maka dalam tahap awal multimedia interaktif yang dikem-bangkan adalah hanya untuk pelajaran matematika kelas II semester 1.

\section{Rumusan Masalah}

Berdasarkan uraian di atas maka masalah dapat dirumuskan

sebagai berikut. Bagaimana bentuk multimedia interaktif matematika dan pemanfaatannya dalam pembelajaran pada Kejar Paket B?

\section{Tujuan Umum}

Tujuan umum penelitian ini ialah menemukan bentuk multimedia interaktif matematika dan pola pemanfaatannya dalam pembelajaran matematika.

\section{Tujuan Khusus}

Secara khusus penelitian ini bertujuan untuk hal-hal berikut.

1. Memperoleh bahan belajar yang berbentuk multimedia interaktif matematika yang mampu meningkatkan minat dan prestasi belajar warga belajar.

2. Memperoleh multimedia interaktif yang berfungsi sebagai alat evaluasi hasil belajar.

3. Memberikan pengenalan ICT khususnya komputer kepada warga belajar Paket B sehingga lebih mendekatkan teknologi tersebut dalam kehidupan sehari-hari mereka dan lebih siap dalam menyerap teknologi lebih lanjut. 


\section{KAJIAN TEORI}

\section{Pembelajaran Matematika}

Matematika merupakan suatu bahan kajian yang memiliki obyek abstrak dan dibangun melalui proses penalaran deduktif, yaitu kebenaran suatu konsep diperoleh sebagai akibat logis dari kebenaran sebelumnya yang sudah diterima, sehingga keterkaitan antar konsep dalam matematika bersifat sangat kuat dan jelas (konsisten). Namun demikian, pembelajaran dan pemahaman konsep dapat diawali secara induktif melalui pengalaman peristiwa nyata atau intuisi. Proses induktif-deduktif dapat digunakan untuk mempelajari konsep matematika. Kegiatan dapat dimulai dengan beberapa contoh atau fakta yang teramati, membuat daftar sifat yang muncul (sebagai gejala) memperkirakan hasil baru yang diharapkan, yang kemudian dibuktikan secara deduktif. Dengan demikian, cara belajar induktif dan deduktif dapat digunakan dan sama-sama berperan penting dalam mempelajari matematika.

Matematika berfungsi untuk mengembangkan kemampuan bernalar melalui kegiatan penyelidikan, eksplorasi dan eksperimen, sebagai alat pemecahan masalah melalui pola pikir dan model matematika serta sebagai alat komunikasi melalui simbol, tabel, grafik, dan diagram dalam menjalankan gagasan. Dengan demikian, tujuan pembelajaran matematika adalah melatih peserta didik agar terbiasa berpikir secara sistematis, logis, kritis, dan konsisten.

Standar Kompetensi Matematika merupakan seperangkat kompetensi yang dibakukan dan harus dicapai oleh peserta didik pada akhir periode pembelajaran. Standar ini dikelompokkan dalam Kemahiran Matematika, Bilangan, Pengukuran dan Geometri, Aljabar, Statistika dan Peluang, Trigonometri.

\section{Teknologi Multimedia}

Multimedia adalah gabungan dari kata "multi" dan "media". Multi berarti banyak atau lebih dari satu, dan media berarti bentuk atau jenis sarana yang dipakai untuk menyampaikan informasi. Penggunaan televisi, video, dan film merupakan contoh penyampaian informasi yang melibatkan beberapa komponen sekaligus, namun yang membedakan aplikasi multimedia dengan yang lainnya adalah adanya interaksi antara aplikasi dengan manusia yang menggunakannya.

Multimedia juga diartikan sebagai suatu sistem komputer yang terdiri dari hardware dan software yang memberikan kemudahan untuk menggabungkan berbagai komponen seperti gambar, video, grafik, animasi, suara, teks, dan data yang dikendalikan dengan program komputer. Lima tipe dasar objek media:

1. Gambar

Multimedia dapat menyediakan objek yang berupa gambar dalam bentuk foto, grafik, peta dan gambar-gambar yang lain. Untuk memproduksi gambar dapat digunakan kamera digital, mencari gambar dari berbagai sumber, dan download gambar yang ada di internet.

2. Tulisan

Tulisan sebagai penyerta untuk mengkomunikasikan informasi yang disampaikan, memperjelas media lainnya atau untuk tujuan ekspresi artistik.

3. Suara

Elemen bunyi-bunyian (musik, efek suara) untuk memperjelas informasi yang diberikan. Bisa juga dengan penggunaan secara terpisah untuk memperjelas elemen media lain.

4. Gerakan

Animasi (tipe kartun, video, dan lain-lain) dapat digunakan sebagai alternatif untuk memperjelas dan menjadikan lebih menarik dalam penyampaian informasi. Animasi dapat juga menyajikan beberapa gabungan gambar yang ditampilkan secara berurutan. 5. Interaktivitas

Seseorang dapat mengoperasikan sendiri peralatan yang digunakan sesuai dengan kebutuhan, yang akan memperkuat rasa percaya diri pengguna (user).

Pendapat lain menyatakan, konsep multimedia meliputi tiga level. Pertama, level teknis yang berkaitan dengan alat-alat teknik; alat-alat ini dapat dianggap sebagai kendaraan yang mengangkut tanda-tanda (signs). Kedua, level semiotik yang berkaitan dengan bentuk representasi (yaitu teks, gambar, atau grafik); bentuk representasi ini dapat dianggap sebagai jenis tanda (types of signs). Ketiga, level sensorik, yaitu berkaitan dengan saluran sensorik yang berfungsi untuk menerima tanda (signs). Ketiga konsep multimedia tersebut tidak dapat diabaikan, karena pengabaian terhadap salah satu level tersebut akan membawa pada kesalahan. Ketika multimedia dianggap sebagai teknologi informasi semata, berarti hanya bicara satu level saja (yaitu level teknik). Padahal, dua level lainnya (level semiotic dan sensorik) juga sama pentingnya, dan kedua level ini membutuhkan keahlian bidang ilmu kognitif, psikologi, ilmu pendidikan, dan semiotik. Waktu dan uang yang diinvestasikan pada multimedia akan sia-sia apabila 
multimedia hanya terbatas pada satu level saja, bukan ketiga-tiganya.

\section{Multimedia interaktif}

Beberapa keistimewaan multimedia adalah menyediakan proses interaktif dan memberikan umpan balik, serta memberikan kebebasan kepada pengguna dalam menentukan topik yang hendak dipelajarinya, kebebasan memilih topik ini adalah salah satu karakteristik pembelajaran menggunakan komputer. Bahan-bahan pelajaran dan data yang tersimpan dapat ditampilkan kembali secara cepat, tepat dan mudah. Proses interaktif terjadi karena kapasitas yang dimiliki multimedia (menggabungkan dua jalur antara siswa dan guru yang menciptakan dialog). Sedangkan konsep umpan balik yang disediakan program multimedia dapat menentukan tingkat kreativitas terhadap suatu pemecahan masalah.

Multimedia interaktif juga membantu tutor terutama pada topiktopik tertentu yang sulit disampaikan secara tradisional atau membutuhkan akurasi yang tinggi. Dapat juga dipergunakan untuk menuntun untuk bereksplorasi dan menganalisis, mencoba dan menggali konsep dan prinsip yang termuat dalam materi yang dihadapi.

Ada banyak alasan kuat mengapa multimedia dapat membuat pembelajaran lebih menarik sehingga dapat meningkatkan kemampuan sumber daya manusia (SDM), karena multimedia sangat sesuai dengan karakteristik utama pembelajaran. Saat ini "belajar" dipandang sebagai proses yang aktif, konstruktif, kumulatif dan berorientasi pada tujuan. Menurut pandangan konstrukstivis dalam pembelajaran, multimedia menawarkan layanan-layanan secara spesifik. Film dan video clip dapat menyajikan "authentic learning situation" (situasi pembelajaran yang otentik) yang dapat menumbuhkan motivasi warga belajar dan menyediakan "situatedness of learning" (pembelajaran yang dikondisikan) yang memadai. Gambar statik dan animasi akan dapat membuat presentasi menjadi lebih konkrit dan realistik. Perpaduan antara gambar dan suara cocok prinsip penyajian informasi melalui multi-saluran sensorik. "Computer-based multimedia" (multimedia berbasis komputer) memungkinkan terjadinya interaksi antara warga belajar dengan isi pembelajaran: "self-directed exploratory learning" (eksplorasi pembelajaran mandiri) warga belajar dapat memanipulasi objek pembelajaran dan mengamati hasilnya.

Multimedia Interaktif Sebagai Sarana

\section{Pembelajaran Matematika}

Implikasi dari pembelajaran matematika pada saat ini diarahkan pada: (1) mengembangkan kemampuan berpikir matematis meliputi pemahaman, pemecahan masalah, penalaran, komunikasi, dan koneksi matematis; dan (2) mengembangkan kemampuan berpikir kritis, sikap terbuka, dan objektif.

Pada pembelajaran mate-matika, beberapa topik matematika yang sulit disampaikan secara konvensional atau sangat membutuh-kan akurasi yang tinggi, dapat dilaksanakan dengan bantuan teknologi komputer atau multimedia. Selain itu, perbedaan individual siswa, sesuai dengan kecepatan dan kemampuan belajar dapat dibantu dengan layanan program komputer yang disesuaikan dengan bahan ajar yang diperlukan dan komunikasi yang berlangsung antara siswa dan komputer di bawah fasilitator guru diwujudkan dalam bentuk stimulusrespon.

Penyederhanaan materi terutama yang menyangkut prinsip dasar setiap teori dapat ditempuh dengan penggunaan multimedia, sehingga kesan rumit pada pelajaran matematika akan hilang pada diri siswa. Melalui multimedia interaktif dapat disajikan cakupan pengetahuan yang lebih luas dan lengkap. Multimedia interaktif memiliki kapabilitas untuk menghidupkan gambar, suara, dan peristiwa. Siswa dapat memanfaatkan semua fasilitas tersebut dengan mudah dan dapat meresponnya dengan mudah pula.

Selanjutnya dengan multimedia interaktif siswa dapat menentukan sendiri topik mana dahulu yang perlu dipelajari sesuai dengan minatnya. Kebebasan memilih topik ini adalah salah satu karakteristik pembelajaran dengan menggunakan komputer. Bahan-bahan pelajaran dan data yang tersimpan dapat ditampilkan kembali secara tepat dan mudah, dan memberikan kemudahan kontrol yang sistematis dalam proses belajar. Hal itu memungkinkan siswa menentukan arah belajar yang harus diambil, serta gaya dan strategi belajar yang akan diterapkan.

Tahapan komunikasi yang dilalui siswa dalam belajar melalui teknologi multimedia interaktif diantaranya: (1) komputer menyajikan materi pelajaran, (2) siswa mempelajari materi tersebut, (3) komputer mengajukan pertanyaan, (4) siswa memberikan respon, dan (5) komputer memeriksa respon tersebut. Bila benar, komputer menyajikan materi berikutnya, tetapi jika jawaban salah, komputer memberikan 
Multimedia Interaktif Sebuah Terobosan...

jawaban benar dan penjelasan. Pada tingkat 2 dapat diperkaya dengan bentuk-bentuk interaksi yang lebih variatif, misalnya siswa yang mengajukan pertanyaan, komputer menjawab, siswa meminta komputer untuk mengerak-gerakkan objek-objek yang tampak dalam layar atau sebaliknya komputer yang meminta siswa untuk mengerak-gerakkan objek-objek tersebut.

Dengan demikian, karakter pengajaran yang interaktif, simulatif, dialogis, pedagogis, dan sebagainya dapat dirasakan oleh siswa. Dengan teknologi yang sudah ada pembelajaran melalui komputer (multimedia interaktif) mampu mendiagnosa kesulitan belajar seseorang dan berperan sebagai pembimbing, penguji dan penyimpan file kemampuan seseorang.

Memperhatikan uraian di atas, dapat dilihat betapa besar peran komputer dan programnya dalam membantu pendidikan. Tentang program komputer ini Retno $(2006,11)$ merangkum beberapa hal yang mampu dilakukan oleh sebuah komputer dengan program yang baik yaitu:

1. memvisualisasikan berbagai konsep,

2. melakukan latihan terus-menerus,

3. menampilkan berbagai fungsi secara acak,

4. berperan sebagai tutor,

5. melakukan pengulangan,

6. berfungsi sebagai alat bantu,

7. menyelesaikan berbagai masalah dan mendesain,

8. membuat program,

9. berinteraksi, dan

10.berfungsi sebagai alat komunikasi.

Namun demikian, Retno (2006:11) juga mengingatkan bahwa selain kemampuan yang dimiliki tersebut, komputer juga memunculkan berbagai dampak yaitu:

1. belajar lebih lama dan menghilangkan kebosanan,

2. memudahkan anak menangkap konsep-konsep yang sulit dan menghindarkan terjadinya penerimaan konsep yang salah,

3. meningkatkan kecerdasan intelektual dan emosi,

4. meningkatkan kreatifitas,

5. membuat produktif,

6. menghilangkan stres, dan

7. mendorong untuk bersifat sosial.

\section{CD-ROM Sebagai Media Interaktif}

Pemilihan CD-ROM sebagai media penyampaian dalam pengembangan multimedia interaktif adalah karena CD-ROM mempunyai kemampuan untuk menampilkan multimedia secara optimal serta sifat kemudahannya dalam menyajikan serta mengupdate (memperbaharui) isinya. Gambar berikut ini memperlihatkan sebuah batasan keputusan $50 \mid$ Jurnal IImiah VISI PTK-PNF - Vol. 1, No.1, 2006 yang sederhana untuk membantu menentukan media penyampaian yang tepat yang akan digunakan dalam pengembangan multimedia Interaktif, apakah menggunakan CD-ROM atau WBT (Web Based Training).

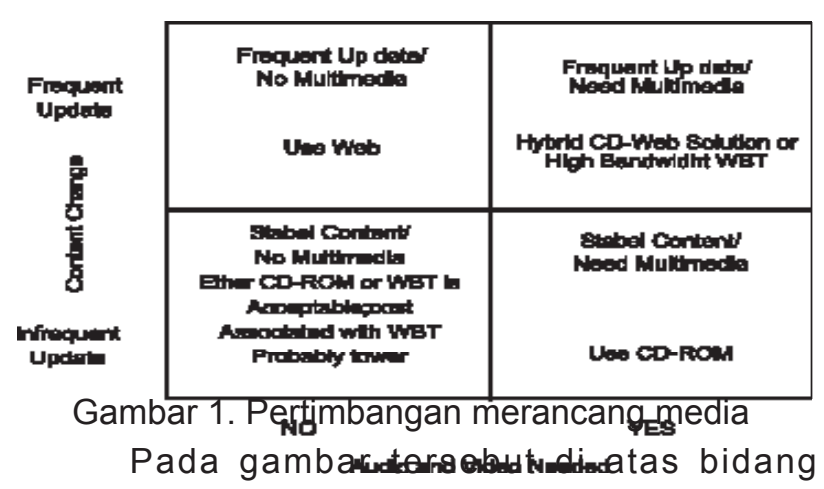

horizontal adalah kebutuhan akan video dan audio, sementara itu bidang vertikal adalah kebutuhan akan perubahan konten. Apabila materi yang disampaikan membutuhkan update (pembaharuan yang berulangulang dalam satu tahun tanpa konten multimedia), dapat dipilih media Web sebagai e-leaming. Namun apabila materi yang disampaikan tidak mengalami perubahan selama satu tahun, dapat digunakan media CD-ROM. Selanjutnya jika materi yang disampaikan mengalami perubahan yang berkali-kali dalam satu tahun serta membutuhkan multimedia (audio dan video) dapat digunakan solusi Hybrid $C D$ atau menggunakan WBT dengan bandwith yang besar.

\section{Spesifikasi dan Pemanfaatan Multimedia Interaktif}

Multimedia yang dihasilkan terdiri dari dua buah yaitu (1) multimedia interaktif sebagai bahan belajar dan (2) multimedia interaktif sebagai alat evaluasi.

\section{Spesifikasi}

Spesifikasi yang diuraikan mencakup spesifikasi bahan ajar multimedia interaktif, tes interaktif, hardware pendukung dan software pendukung.

1. Spesifikasi bahan belajar multimedia interaktif.

Bahan belajar ini dikembangkan untuk pembelajaran matematika pada paket B kelas II semester 1. Secara rinci spesifikasi dari multimedia ini adalah sebagai berikut.

a. Judul Media : Media belajar interaktif

b. Judul Materi : Sistem Persamaan Linear Dua Variabel

c. Alokasi Waktu $\quad: 8$ jam pelajaran (khusus untuk klasikal)

d. Pemanfaatan : Pembelajaran klasikal dan 
mandiri
e. Aplikasi
: Tanpa proses installing.

2. Spesifikasi multimedia interaktif tes

Alat evaluasi ini pada awalnya dikembangkan untuk pembelajaran matematika pada paket B kelas II semester 1, kemudian dikembangkan sehingga dapat digunakan untuk semua mata pelajaran dan semua kelas serta jenjang pendidikan, tergantung pada materi yang diinputkan. Secara rinci spesifikasi dari multimedia ini adalah sebagai berikut.
a. Judul Media : Tes Interaktif
b. Judul Materi : Tergantung pada input
c. Alokasi Waktu : Tergantung setting yang dilakukan
d. Pemanfaatan
: Mandiri
e. Aplikasi
: Melalui proses installing.

Saat ini software tes interaktif yang disusun hanya dapat digunakan secara single user, namun tidak menutup kemungkinan untuk dikembangkan sebagai software untuk multi users.

\section{Spesifikasi hardware pendukung}

Untuk mengoperasikan kedua multimedia interaktif ini diperlukan komputer dan monitor sebagai berikut.

a. komputer dengan: (1) prosesor minimal Pentium II multimedia; (2) memori minimal $64 \mathrm{MB}$; dan (3) hard disk minimal $4 \mathrm{~GB}$;

b. monitor dengan layar minimal 17 inchi untuk pembelajaran klasikal, sedang untuk pembelajaran mandiri dapat menggunakan monitor 14" atau 15 ". Monitor yang digunakan disarankan yang memiliki resolusi 1024 x 768; dan

c. active speaker standar yang mampu menjangkau area seluas $4 \times 4 \mathrm{~m}^{2}$ dengan jelas.

4. Spesifikasi software pendukung

Untuk dapat menjalankan multimedia interaktif tersebut (bahan ajar dan tes interaktif) selain sistem operasi windows, juga dibutuhkan beberapa software pendukung antara lain (1) flash player, (2) microsoft word (khusus untuk tes interaktif)

\section{Pemanfaatan Media dalam Pembelajaran}

Untuk dapat memanfaatkan multimedia yang telah dikembangkan baik untuk bahan ajar maupun interaktif, terlebih dahulu harus dilakukan kegiatan orientasi bagi tutor dan warga belajar. Materi yang diorientasikan adalah pengenalan komputer, pengenalan bahan ajar, dan software tes interaktif.

1. Orientasi pengenalan komputer

Kegiatan ini dilakukan sebagai upaya memberikan dasar kepada tutor dan warga belajar terhadap perangkat yang ada di komputer dan operasionalnya (khusus untuk windows). Kedalaman orientasi bagi tutor dan warga belajar sangat berbeda. Orientasi kepada warga belajar lebih ditekankan bagaimana menghidupkan dan mematikan, serta menjalankan mouse untuk masuk pada aplikasi tertentu, sedangkan orientasi untuk tutor ditambah dengan materi troubleshooting yang bertujuan untuk memberikan wawasan bagi tutor untuk melakukan perawatan dan perbaikan jika terjadi berhentinya proses secara tibatiba (hang).

Kegiatan ini dilaksanakan jika terbukti bahwa asumsi tutor dan warga belajar belum pernah menggunakan atau memanfaatkan komputer telah terbukti. Jika ternyata tutor dan warga belajar teiah menguasai penggunaan komputer, maka kegiatan orientasi tidak perlu dilaksanakan.

2. Orientasi bahan belajar.

Bagi tutor kegiatan ini dilaksanakan untuk memberikan pemahaman terhadap tombol-tombol navigasi yang ada ada multimedia. Di samping itu orientasi dilakukan untuk menjelaskan pola pikir penyajian materi dalam multimedia. Sementara itu bagi warga belajar orientasi dilakukan hanya untuk membiasakan dengan tombol-tombol navigasi yang ada.

3. Orientasi software tes interaktif.

Dalam orientasi ini dilakukan pengenalan software dalam pengertian bahwa tutor dan warga belajar diajarkan cara mengoperasionalkan software tersebut dan cara menggunakan software tersebut. Untuk tutor, orientasi dilakukan dengan lebih mendalam yaitu juga pada cara penggunaan akses yang diberikan oleh pembuat software berkenaan dengan hak dalam merubah dan memperkaya soal-soal pada software evaluasi belajar.

Setelah tutor dan warga belajar sudah memiliki keterampilan dalam menjalankan komputer dan memiliki pemahaman dalam mengoperasikan software, selanjutnya proses belajar mengajar dapat berjalan dapat dilaksanakan dengan harapan tidak ada gangguan teknis dalam pengoperasian komputer dan penggunaan software.

Pemanfaatan bahan belajar multimedia interaktif dalam pembelajaran dapat dilakukan pada pembelajaran klasikal dan mandiri. Sebaiknya pembelajaran dengan menggunakan multimedia ini dilaksanakan secara kombinasi, artinya pembelajaran secara klasikal dan mandiri. Sementara software interaktif hanya dapat dilakukan secara individual dengan pengawas-an tutor.

a. Strategi klasikal

Pada strategi ini tutor benar-benar berfungsi sebagai fasilitator. Tutor berperan membimbing dan memfasilitasi warga belajar dalam menggunakan 
software untuk membantu proses belajar di kelas. Bimbingan dan arahan yang diberikan tutor harus lebih mengarah pada peningkatan pemahaman dan pengayaan materi.

Kondisi minimal yang harus ada dengan strategi ini adalah ketersediaan seperang-kat komputer multimedia yang diletakkan di dalam kelas dengan monitor 17". Proses berikutnya, tutor secara aktif mengajak warga belajar untuk mencermati, dan mentransfer pola belajar serta memberikan kebebasan warga belajar untuk bereks-plorasi dengan program pelajaran interaktif yang ada. Ini dilakukan dengan meminta satu atau dua warga belajar untuk maju ke depan, untuk mengoperasikan langsung media tersebut. Transfer berikutnya akan menjadikan warga belajar tersebut sebagai penyebar instruksi kepada rekan sekelas (sebaya).

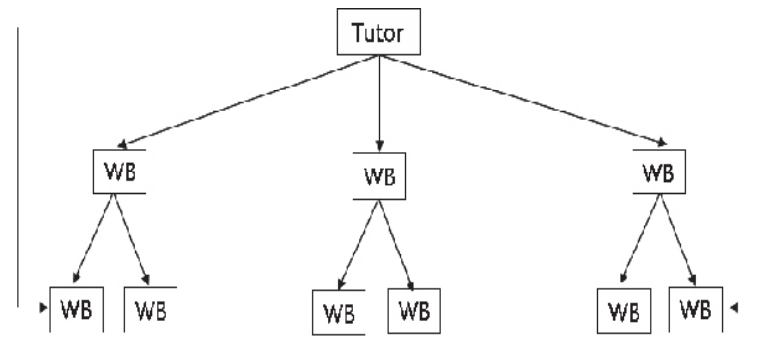

Gambar 2. Skema perjalanan instruksi dan pembelajaran dalam kelompok

Strategi pengelompokan yang digunakan dalam pembelajaran klasikal dapat menggunakan metode cooperative learning (CL) yang sangat menekankan kerjasama dalam kelompok. Tiap individu dalam kelompok memiliki peran meskipun komposisi kelompok bervariasi. Individu dalam kelompok yang lebih unggul dan yang lain wajib membantu individu yang lain dalam kelompoknya, namun demikian peran tidak menjadi dominasi individu yang dipandang lebih unggul. Aktualisasi tiap individu dalam kelompok mempengaruhi hasil kelompok secara keseluruhan. Dengan demikian akan terjadi interaksi yang saling menguntungkan dan saling membelajarkan antaranggota kelompok tersebut.

Pada CL terdapat beberapa kunci utama yang perlu diperhatikan. Pertama, adanya saling ketergantungan positif antar anggota dalam kelompok. Kedua, adanya tanggung jawab individual pada masing-masing anggota kelompok. Ketiga, adanya interaksi dengan tatap muka. Keempat, adanya upaya untuk membangun komunikasi dalam kelompok, dan kelima adanya proses dalam kelompok.

Setting kelas pada pembelajaran interaktif ini menggunakan desain seperti yang tergambar di bawah ini. Jarak maksimal (terjauh) antara komputer dan warga belajar adalah 2,5 m, dengan lebar $3 \mathrm{~m}$. Apabila komputer yang digunakan adalah 1 unit.

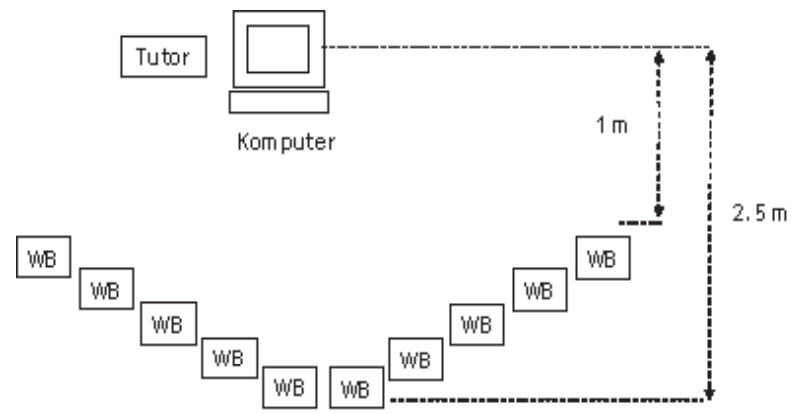

Gambar 3. Skema pengaturan ruangan belajar klasikal

Setelah seluruh materi terselesaikan, kegiatan selanjutnya adalah evaluasi. Untuk evaluasi dapat digunakan software evaluasi yang telah didesain untuk individu. Karena komputer hanya satu maka evaluasi dengan software ini hanya dapat dilakukan secara individu dengan bergiliran. Agar waktu dapat dimanfaatkan optimal maka soal ulangan harus dipilih yang pokok-pokok saja dengan waktu yang relatif pendek. Jika komputer yang dimiliki minimal 5, maka evaluasi dapat dilakukan lebih cepat.

b. Strategi belajar mandiri

Prasyarat sebagai penunjang terlaksananya strategi belajar mandiri ini adalah warga belajar dibekali dengan orientasi awal tentang program interaktif secara aplikatif. Berikutnya, diberikan copy software dan buku manual penggunaan software untuk digunakan dan dimanfaatkan di luar panti belajar (di manapun dan kapanpun warga belajar dapat memanfaatkannya).

Hal ini dapat dilakukan karena aplikasi software yang digunakan telah didesain untuk digunakan tanpa proses peng-install-an. Berbekal CD pembelajaran tersebut warga belajar dapat belajar sendiri dengan menggunakan komputer milik sendiri atau menyewa (rental). Setelah semua materi dapat dipelajari dan latihan-latihan dikerjakan, warga belajar dapat melaksanakan evaluasi.

Kekuatan keberhasilan dari strategi belajar mandiri ini ada pada kemauan warga belajar dalam memanfaatkan dan menggunakan software program belajar secara mandiri dan optimal di luar panti belajar. Pemanfaatan waktu di luar jam pelajaran dengan menggunakan software program belajar secara mandiri akan dapat mengoptimalkan waktu warga belajar, sehingga pertemuan yang terbatas dengan tutor (tatap muka dengan tutor di panti belajar) dapat dioptimalkan untuk memecahkan masalah atau materimateri yang sulit serta membahas soal-soal latihan yang belum terselesaikan saat belajar mandiri. Dengan 
demikian kondisi atau fakta adanya keterbatasan tatap muka dengan tutor bukan menjadi kendala lagi.

Belajar mandiri diharapkan selain akan meningkatkan kemampuan warga belajar juga akan mempermudah bagi warga belajar untuk terbiasa menggunakan media dalam mempermudah proses belajar dan mempercepat tercapainya tujuan belajar. Berikut ini alur perlakuan yang diberikan pada warga belajar dalam proses pembelajarannya.

Keseluruhan proses pembelajaran yang dilakukan dengan memanfaatkan multimedia ini dapat digambarkan pada alur sebagai berikut.

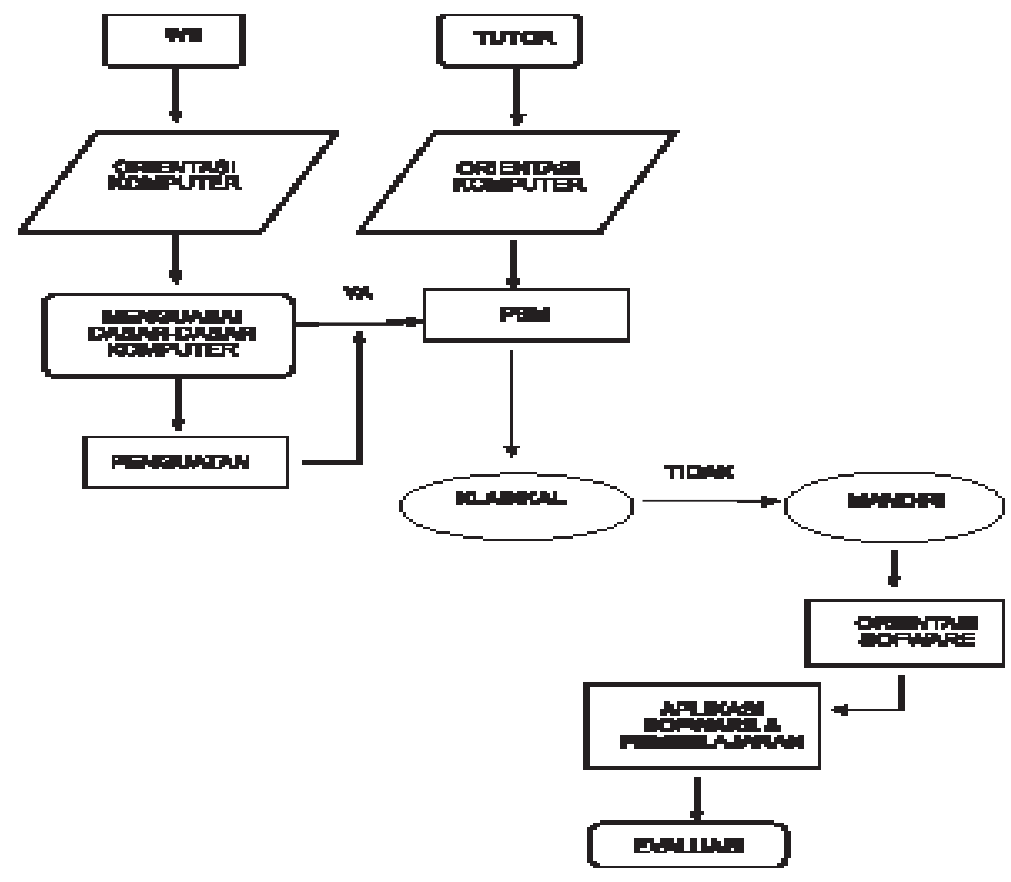

Gambar 4. Alur proses pembelajaran

\section{HASIL PENELITIAN}

Pemanfaatan multimedia interaktif ini dalam ujicoba telah memberikan hasil dan dampak bagi warga belajar.

\section{Prestasi Belajar Warga Belajar}

Prestasi belajar dapat dilihat melalui evaluasi terhadap perubahan prestasi warga belajar yaitu perbedaan sebelum dan sesudah menggunakan software. Evaluasi dilakukan terhadap aspek kemampuan yaitu melalui pre test dan post test, aspek afektif yaitu sikap dan minat, serta aspek unjuk kinerja yaitu penguasaan keterampilan. Penguasaan keterampilan dibedakan menjadi dua hal yaitu: (1) penguasaan keterampilan terhadap komputer dan (2) penguasaan terhadap software test interaktif. Untuk rnemperoleh hasil evaluasi terhadap afektif dan psikomotor warga belajar dilakukan melalui observasi terhadap masing-masing warga belajar menggunakan instrumen yang telah disusun. Kriteria untuk evaluasi kemampuan, afektif dan psikomotor menggunakan acuan seperti pada tabel berikut.

Tabel 1. Kriteria evaluasi kemampuan, afektif dan psikomotor

\begin{tabular}{|c|c|}
\hline Nilai & Kategori \\
\hline $85-100$ & Sangat Bak \\
\hline $70-84$ & Bak \\
\hline $55-69$ & Cukup Bak \\
\hline $40-54$ & Kurang Baik \\
\hline $0-39$ & Tidak Baik \\
\hline
\end{tabular}

Tabel 2. Rekapitulasi pre test dan post test secara keseluruhan

\begin{tabular}{|c|c|c|c|c|}
\hline \multirow{2}{*}{ No } & \multicolumn{5}{|c|}{ Hasil Evaluasi Kemampuan } \\
\cline { 2 - 5 } & Pre Test & Kriteria & Post Test & Kriteria \\
\hline 1 & 10 & Sangat Kurang Bak & 50 & Kurang Bak \\
\hline 2 & 50 & Kurang Bak & 60 & Cukup Baik \\
\hline 3 & 60 & Cukup Bak & 80 & Bak \\
\hline 4 & 50 & Kurang Bak & 80 & Bak \\
\hline 5 & 70 & Baik & 90 & Sangat Bak \\
\hline 6 & 50 & Kurang Bak & 100 & Sangat Bak \\
\hline 7 & 30 & Sangat Kurang Bak & 80 & Bak \\
\hline 8 & 60 & Cukup Bak & 90 & Sangat Bak \\
\hline 9 & 40 & Kurang Bak & 90 & Sangat Bak \\
\hline 10 & 30 & Sangat Kurang Bak & 60 & Cukup Baik \\
\hline Rerata & 45 & Kurang Bak & 78 & Bak \\
\hline
\end{tabular}

dapat dilihat bahwa nilai terendah pre test adalah 10 sedangkan tertinggi 70 dan ráta-ratanyal 45 , 
Multimedia Interaktif Sebuah Terobosan...

Sedangkan untuk nilai post test diperoleh nilai terendah adalah 50, nilai tertinggi 100 dan rata-ratanya adalah 78.

Berdasarkan kriteria yang ada untuk hasil pre test diperoleh hasil sangat kurang baik sebanyak 3 responden (30\%), kurang baik sebanyak 4 responden (40\%), cukup baik sebanyak 2 responden (20\%) dan sebanyak 1 responden dinyatakan baik (10\%). Dengan kriteria yang sama pada hasil pre test, hasil post test pada uji coba kali ini diperoleh hasil kurang baik sebanyak 1 responden (10\%), cukup baik sebanyak $20 \%$ dari 10 responden, dan hasil 30\% mendapat kriteria baik, kriteria sangat baik dihasilkan dari 4 responden (40\%).

Hasil evaluasi kemampuan keseluruhan dari pre test diperoleh rata-rata 45 dengan kriteria kurang baik sedangkan pada penilaian post test kita memperoleh rata-rata 78 yang masuk pada kriteria baik. Dengan demikian jika kita bandingkan hasil pre test dan post test terdapat peningkatan hasil sebesar $42 \%$.

Tabel 3. Rekapitulasi untuk aspek sikap, minat dan keterampilan warga belajar

\begin{tabular}{|c|c|c|c|}
\hline \multirow{2}{*}{$\begin{array}{l}\text { No. } \\
\text { W'B }\end{array}$} & \multicolumn{3}{|c|}{ Hasil Evaluaヨi } \\
\hline & Skap & Minat & Keterampilan \\
\hline 1 & B aik & B aik & $\mathrm{Bak}$ \\
\hline 2 & B aik & B aik & B ak \\
\hline 3 & B aik & B aik & $\mathrm{B}$ ak \\
\hline 4 & Baik & B aik & $\mathrm{B}$ ak \\
\hline 5 & Baik & B aik & $\mathrm{Bak}$ \\
\hline 6 & B aik & B aik & $\mathrm{B}$ ak \\
\hline 7 & B aik & B aik & Bak \\
\hline 8 & B aik & B aik & Bak \\
\hline
\end{tabular}

9D a ri rekabitula\$ di atais (Tabel 3)Edàpat dilihat

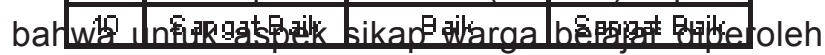
bahwa terdapat 9 warga belajar mempunyai sikap baik $(90 \%)$ dan 1 warga belajar bersikap sangat baik (10\%), untuk aspek minat kita memperoleh hasil baik sebanyak 10 warga belajar (100\%); untuk aspek keterampilan, 9 warga belajar menyatakan baik (90\%) dan 1 warga belajar menyatakan sangat baik (10\%).

Untuk menentukan perbedaan kemampuan, dilakukan dengan menggunakan tes non parametrik. Penggunakan tes non parametrik ini terjadi akibat banyaknya data yang kurang dari 30 . Uji statistik menggunakan Wilcoxon dan uji tanda (sign test) dengan hasil bahwa $z=-2,820$ dan asymp.sig ( 2 tailed) $=0,005$ yang berarti lebih kecil dari $\mathrm{a}=0,05$ sehingga dapat dikatakan ada perbedaan secara signifikan kemampuan sebelum dan sesudah perlakuan pada taraf kepercayaan 95\%, sedangkan uji tanda diperoleh bahwa exact signifikansi ( 2 tailed $)=0,002$ yang berarti signifikan untuk penggunaan distribusi normal. Dari dua hasil ini dapat dikatakan bahwa ada perbedaan yang sangat signifikan antara kemampuan sebelum dan sesudah penggunaan bahan belajar multimedia pada taraf kepercayaan $95 \%$.

Untuk hasil evaluasi keterampilan terhadap penggunaan software tes interaktif oleh warga belajar digunakan kriteria sebagai berikut.

Tabel 4. Kriteria evaluasi kemampuan, afektif, dan psikomotorik

\begin{tabular}{|c|c|}
\hline Nilai & Kategori \\
\hline $30 \mathrm{ke}$ atas & Sangat $\mathrm{B} a \mathrm{k}$ \\
\hline $23.33<$ Nilai $<30$ & Bak \\
\hline 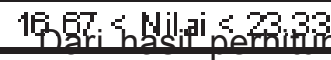 & 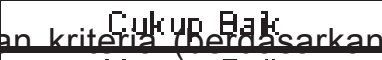 \\
\hline
\end{tabular}

Tabel 5. Hasil perhitungan kriteria evaluasi keterampilan

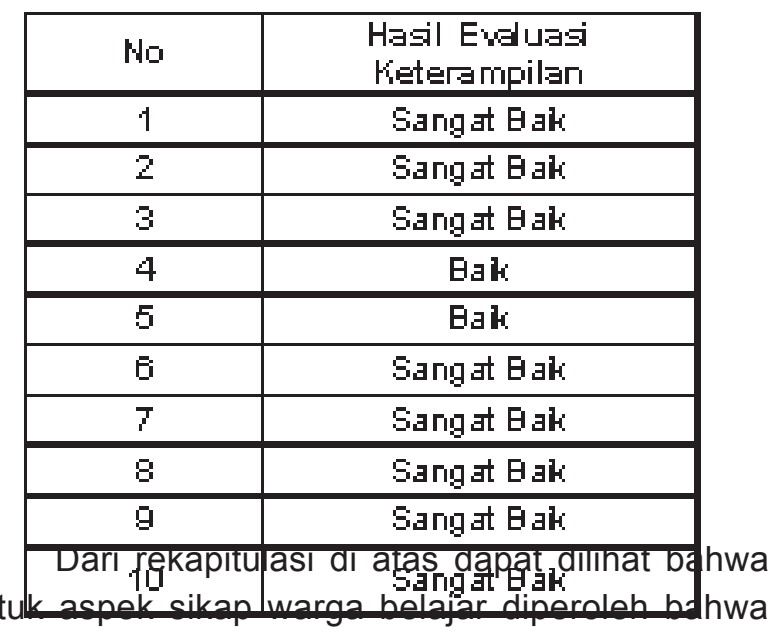

untuk aspek keterampilan, 2 warga belajar menyatakan baik $(20 \%)$ dan 8 warga belajar menyatakan sangat baik (80\%).

Untuk menentukan perbedaan kemampuan antara nilai kontrol yang berasal dan nilai yang bersumber dari tutor mata pelajaran dan nilai eksperimen yang diperoleh dari ujicoba (kedua nilai terlampir), dilakukan dengan menggunakan tes nonparametrik. Penggunaan tes nonparametrik ini terjadi akibat banyaknya data yang kurang dari 30 . Uji statistik menggunakan Wilcoxon dan uji tanda (sign test) dengan hasil bahwa $z=-2,527$ dan asymp. sig (2 tailed) - 0,012 yang berarti lebih kecil dari a $=0,05$ sehingga dapat dikatakan ada perbedaan 
secara signifikan kemampuan sebelum dan sesudah perlakuan pada taraf kepercayaan 95\%, sedangkan uji tanda diperoleh bahwa exact sig. (2 tailed $)=$ 0,008 yang berarti signifikan untuk penggunaan distribusi normal. Dari dua hasil ini dapat dikatakan bahwa ada perbedaan yang sangat signifikan antara kemampuan sebelum dan sesudah perlakuan pada taraf kepercayaan 95\%.

\section{Dampak Sosial Budaya}

Dampak sosial budaya dari pengembangan media ini adalah terciptanya suasana belajar yang lebih bervariasi. Hal ini dikarenakan selama ini pembelajaran dilaksanakan secara manual dengan menggunakan modul-modul yang ada. Kenyataan bahwa pembelajar-an menggunakan media interaktif lebih menarik dapat dilihat dari respon warga belajar yang antusias dalam proses pelaksanaan. Mereka menyatakan bahwa sangat senang sekali jika diadakan pembelajaran seperti ini.

\section{KESIMPULAN DAN SARAN}

\section{Kesimpulan}

Kegiatan pengembangan media belajar ini merupakan salah satu upaya pengembangan media yang berbasis ICT, media yang digunakan berbentuk multimedia interaktif. Untuk dapat meningkatkan motivasi belajar warga belajar diperlukan sebuah media yang menarik dalam segi judul dan penampilan, mempunyai isi yang mudah dipahami. Tujuan akhir dari pengembangan media ini adalah meningkatnya motivasi dan prestasi warga belajar dalam pembelajaran melalui penggunaan media belajar terutama penggunaan media interaktif.

Pengembangan media ini berupaya untuk memberikan warna yang lebih bervariasi dalam pembelajaran di lingkungan pendidikan luar sekolah, khususnya paket B. Selama ini pembelajaran yang ada masih menggunakan media yang masih terbatas, oleh karena itu dengan adanya pengembangan media interaktif diharapakan proses pembelajaran yang berlangsung dapat berjalan dengan lebih baik.
Tutor juga menyatakan bahwa sangat baik sekali jika banyak bahan belajar multimedia untuk Paket B. Selain pembelajaran akan berjalan lebih bervariasi, prestasi belajar siswa juga akan meningkat karena semangat serta motivasi belajar siswa bertambah.

Dampak lain yang dapat dilihat adanya pengenalan warga belajar terhadap Information Technology (IT). Dengan menggunakan media belajar ini warga belajar secara otomatis akan terbiasa menggunakan komputer sehingga mereka melek media informasi. Seiring dengan itu, kemudahan-kemudahan yang dirasakan membangkitkan kesadaran mereka untuk menggunakan media belajar ini sebagai alat bantu dalam mendapatkan informasi tentang ilmu pengetahuan yang dibutuhkannya.

\section{Saran}

Kegiatan ini merupakan tahap awal dari sebuah upaya pengembangan media dalam proses pembelajaran yang berbasis ICT, yaitu menggunakan multimedia interaktif dalam perancangannya. Sebagai upaya pengembangan media pembelajaran yang lebih baik sebaiknya periu ditindaklanjuti dengan tahap pengembangan media yang lebih bervariasi baik dari segi tampilan maupun jenisnya.

Sebagai upaya mengantisipasi kondisi dimana program paket B tidak lagi menjadi pendidikan yang khusus untuk masyarakat yang kekurangan, maka upaya mengembangkan prasarana menjadi prioritas bagi pengambil kebijakan. Sebagai penunjang pemanfaatan multimedia interaktif sebagai bahan belajar, sarana dan prasarana yang memadahi merupakan prioritas utama bagi pengembangan multimedia sebagai bahan belajar ke arah yang lebih berkualitas.

\section{DAFTAR PUSTAKA}

Hardjito. (2004). Internet untuk pembelajaran. Dari http://www.pustekkom.go.id/teknodik/t10/10-3. $\underline{\mathrm{htm}}$

Ibrahim, N. (2003). Pemanfaatan tutorial audio interaktif untuk perataan kualitas hasil belajar. Jurnal Pendidikan dan Kebudayaan no. 44. Dari http://www.depdiknas.go.id/Jumal/44/nurdin. htm

Kariadinata, R. (2004). Penggunaan multimedia interaktif dalam pelajaran matematika untuk meningkatkan kemampuan berpikir tingkat tinggi siswa, Makalah disajikan pada Seminar Nasional Teknologi Pembelajaran. Jakarta 1-2 Desember 2004

Kurikulum 2004: Standar kompetensi mata pelajaran matematika. (2004). Jakarta: Departemen Pendidikan Nasional.

Lie, A. (2004). Cooperative learning: Mempraktikkan cooperative learning di ruang-ruang Kelas. Jurnal IImiah VISI PTK-PNF - Vol. 1, No.1, 2006 
Jakarta: PT Gramedia Widiasarana Indonesia.

Pramono, H. (2004). Bilamanakah multimedia menunjang kualitas pembelajaran. Makalah disajikan pada Seminar Nasional Teknologi Pembelajaran. Jakarta 1-2 Desember 2004.

Pribadi, B \& Padmo D.P. (2001). Ragam media dalam pembelajaran: Applied approach di perguruan tinggi. PAU-PPAI. Dirjen Dikti. Depdiknas.

Purwanto. (2004). Pengembangan model pembelajaran berbasis teknologi komunikasi dan informasi untuk pendidikan dasar dan menengah. Makalah disajikan pada Seminar Nasional Teknologi Pembelajaran. Jakarta 1-2 Desember 2004.

Retno, D. dkk. (2006). Desain pengenalan membaca dan menghitung anak usia 4-6 tahun melalui permainan interaktif. Desain dipresentasikan pada Seminar Desain Pengembangan dan Kajian BPPSLP Regional IV tanggal 20 - 23 Juni 2006. 